\title{
Changes in Gene Expression Profile in Human Subcutaneous Adipose Tissue during Significant Weight Loss
}

\author{
Céline Leyvraz ${ }^{a, b} \quad$ Chantal Verdumo ${ }^{a}$ b Michel Suter ${ }^{c} \quad$ Alexandre Paroz $^{c}$ \\ Jean-Marie Calmes ${ }^{c}$ Pedro M. Marques-Vidal ${ }^{d}$ Vittorio Giusti $^{a, b}$ \\ a Service of Endocrinology, Diabetes and Metabolism, ${ }^{\mathrm{b}}$ Center for CardioVascular and \\ Metabolic Diseases, ' Department of Surgery, ${ }^{\mathrm{d}}$ Institute of Social and Preventive Medicine, \\ University Hospital CHUV, Lausanne, Switzerland
}

\section{Key Words}

PPAR $\gamma \cdot 11 \beta H S D 1 \cdot$ Roux-en-Y gastric bypass $\cdot$ Subcutaneous adipose tissue

\begin{abstract}
Objective: To analyze the expression of peroxisome proliferator-activated receptor- $\gamma 1$ and 2 (PPAR $\gamma 1$ and 2), 11ß-hydroxysteroid dehydrogenase type 1 (11ßHSD1), and leptin in adipose tissue (AT) of obese women during weight loss following Roux-en-Y gastric bypass (RYGB) and to compare these levels with those obtained in AT of nonobese subjects. Methods: Gene expression was determined by real-time RT-PCR prior to surgery and at 3,6, and 12 months after RYGB. Results: All obese patients lost weight, reaching a mean BMI of $29.3 \pm 1.0 \mathrm{~kg} / \mathrm{m}^{2}$ at 1 year after surgery $(-33.9 \pm 1.5 \%$ of their initial body weight). In obese subjects leptin and $11 \beta H S D 1$ were over-expressed, whereas PPAR $\gamma 1$ was expressed at lower levels compared to controls. After surgery, leptin and $11 \beta H S D 1$ gene expression decreased, whereas PPAR 1 expression increased. At 12 months after RYGB, these 3 genes had reached levels similar to the controls. In contrast, PPAR 22 gene expression was not different between groups and types of tissue and remained unchanged during weight loss. We found a positive correlation between BMI and levels of gene expression of leptin and 11ßHSD1. Conclusion: Gene expression of leptin, PPAR 1 , and $11 \beta H S D 1$ in AT is modified in human obesity. This default is completely corrected by RYGB.

Copyright (c) 2012 S. Karger GmbH, Freiburg
\end{abstract}

\section{Introduction}

Surgical treatment of obesity (reviewed in [1,2]) and its positive consequences on the overall body composition, the inflammation profile, the insulin resistance, the cardiac status, the endothelial function, and the bone status are well documented (reviewed in 
[3-5]). Gene network analysis applied to obesity and caloric restriction, e.g. following bariatric surgery, highlighted the importance of pathways for glycerolipid metabolism (reviewed in [6, 7]). Peroxisome proliferator-activated receptor- $\gamma 1$ and 2 (PPAR $\gamma 1$ and 2)

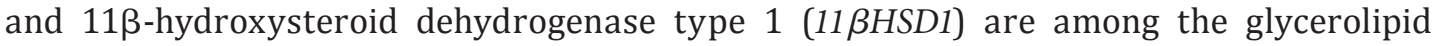
metabolism-related genes. Both PPAR $\gamma$ agonism and inhibition of 11ßHSD1 improve lipid metabolism and lipemia. Moreover, therapeutic inhibition of 11ßHSD1 will be beneficial in most cellular contexts, with clinical trials supportive of this concept. Although the key role of PPAR $\gamma$ and 11ßHSD1 in adipose tissue (AT) development and differentiation are not debated, their mRNA levels in human AT are still controversial.

PPAR $\gamma 1$ and PPAR $\gamma 2$ isoforms are highly expressed in human subcutaneous adipose tissue (SAT) and visceral adipose tissue (VAT) [8-10]. However, the literature does not give a clear view about PPAR $\gamma$ mRNA expression in obesity. Some authors found no difference between obese and nonobese subjects $[8,11,12]$. Some others reported an increase of PPAR $\gamma$ expression in obesity. According to Bortolotto et al. [13], PPAR $\gamma$ expression increase in SAT of obese subjects, decrease in retroperitoneal AT, and is not changed in VAT. For Lefebvre et al. [14], PPAR $\gamma$ in VAT is increased in obesity, but not in SAT. Finally, Vidal-Puig et al. [10] showed that PPAR $\gamma 1$ and PPAR $\gamma 2$ were differently regulated and that only PPAR $\gamma 2$ expression increased in obese versus lean subjects. Consistently, Viguerie et al. [15] reported a decrease of PPAR $y$ expression following 10-week hypocaloric diet program. In contrast, PoulainGodefroy et al. [16] published recently results demonstrating a significant decrease of PPAR $\gamma$ expression in SAT and a trend toward a decrease in VAT of obese compared to lean patients.

$11 \beta H S D 1$ mRNA expression in AT in human obesity is also highly debated in the literature. Several papers reported an overexpression or an overactivity of 11ßHSD1 in AT of obese women and men [17-20]. Polycystic ovary syndrome and obesity are independently associated with increased expression of 11ßHSD1 [21]. Consistently, Mericq et al. [22] demonstrated a positive correlation between mRNA expression of 11ßHSD1 in VAT and BMI in children. However, others studies have failed to show this increase and this relationship $[23,24]$. Tomlinson et al. [25] even showed that weight loss increases 11ßHSD1 expression in human isolated adipocytes. Moreover, data regarding gene expression of $11 \beta H S D 1$ in VAT and SAT are also conflicting [22-24, 26, 27].

The explanation for these discrepancies is not clear. The large variability observed might be related to the degree of sensitivity of the methods or to the criterions of recruitment for the cohorts. Furthermore, discrepancies could be due to circadian pattern in $11 \beta H S D 1$ and PPAR $\gamma$ gene expression [8]. Indeed, clock genes have been recently implicated in the human metabolic syndrome [9-31].

What we propose is to follow the levels of expression of PPAR $\gamma 1, P P A R \gamma 2$, and $11 \beta H S D 1$ genes in SAT and VAT during substantial weight reduction, to compare these levels with those obtained in AT of nonobese subjects, and to determine if the expression of one of these gene is predictive of weight loss. AT were obtained from obese women during Roux-en-Y gastric bypass (RYGB). Additional SAT biopsies were taken by liposuction at the level of the umbilical fold:

a) at 3 months after surgery, during rapid weight loss associated with significant food restriction and hypercatabolism;

b) at 6 months, at a time of moderate weight loss and modest food restriction;

c) 12 months, in steady state conditions. 
Table 1. Anthropometric characteristics of obese and control subjects

\begin{tabular}{llllll}
\hline & Age, years & Weight, kg & Height, cm & BMI, kg/m² & Glycemia \\
\hline Obese & $39 \pm 9(28-62)$ & $117 \pm 16(81-157)$ & $162 \pm 7(146-179)$ & $44 \pm 5(38-56)$ & $6.0 \pm 2.1(4.7-16)$ \\
Ctrl & $39 \pm 8(29-48)$ & $69 \pm 8(62-78)$ & $166 \pm 5(160-172)$ & $25 \pm 2(23-26)$ & $5.5 \pm 0.3(5.2-5.8)$ \\
\hline
\end{tabular}

aData are presented as: mean \pm SD (range). The control (ctrl) group included 5 healthy volunteers, glycemia was known for three of them.

Table 2. Sequences of PCR primers

\begin{tabular}{|c|c|c|c|}
\hline cDNA probe & Direction & Sequence $5^{\prime}-3^{\prime}$ & Product length, bp \\
\hline \multirow[t]{2}{*}{ PPAR $\gamma 1$} & for & AAAGAAGCCAACACTAAACC & \\
\hline & rev & CTTCCATTACGGAGAGATCC & 150 \\
\hline \multirow[t]{2}{*}{$\operatorname{PPAR} \gamma 2$} & for & GCGATTCCTTCACTGATAC & \\
\hline & rev & CTTCCATTACGGAGAGATCC & 123 \\
\hline \multirow[t]{2}{*}{$11 \beta$ HSD1 } & for & GTTTCTGGGATAGTCCATATGCAA & \\
\hline & rev & CCATCAGAAAGGAATATTCAGTG & 164 \\
\hline \multirow[t]{2}{*}{$\beta_{2}$-Microglobulin } & for & TGAGTATGCCTGCCGTGTGA & \\
\hline & rev & GGCATCTTCAAACСTCCATG & 100 \\
\hline \multirow[t]{2}{*}{ Leptin } & for & TCTATGTCCAAGCTGTGCCCAT & \\
\hline & rev & ATAAGGTCAGGATGGGGTGGAG & 168 \\
\hline \multirow[t]{2}{*}{ Adiponectin } & for & GGGCATCCGGGCCATA & \\
\hline & rev & GTT TCACCGATGTCTCCCTTAGG & 116 \\
\hline \multirow[t]{2}{*}{ Glut4 } & for & GCTACСTCTACATCATCCAGAATCTC & \\
\hline & rev & CCAGAAACATCGGCCCA & 78 \\
\hline
\end{tabular}

\section{Participants and Methods}

\section{Subjects}

The study group included 30 obese women and 5 healthy nonobese female volunteers (table 1), matched to the patients by age (39 \pm 2 (range 28-62) years versus $39 \pm 4$ (range 29-48) years), who underwent cholecystectomy and who served as the control group. All selected subjects are Caucasian. They provided informed consent, and the institutional review board approved the study.

\section{Analytical Procedures}

Fasting blood glucose (Ecoline 100 Merck, KgaA, Darmstadt, Germany), total cholesterol (Roche CHOD-PAP; Roche Molecular Biochemicals Systems, GmbH, Mannheim, Germany), high-density lipoprotein cholesterol (HDL-C) (HDL-C plus, second generation; Roche Diagnostic GmbH, Mannheim, Germany), and triglycerides (TG GPO-PAP; Roche Diagnostic) were measured using an automatic Hitachi 917 Roche apparatus. Low-density lipoprotein cholesterol (LDL-C) was then calculated by the Friedwald's formula. Plasma insulin was assayed by specific radioimmunoassay (Aldatis Insulin, code 10624, Casalecchio di Reno, BO, Italy). 
Biopsies, RNA Preparation, and Gene Expression Analysis

AT samples were obtained by biopsy during laparoscopic surgery as previously described [9, 32]. Obese and nonobese patients were operated by the same surgical team for RYGB and removal of the gallbladder, respectively. Moreover, needle biopsies of SAT of obese patients were sampled 3, 6, and 12 months following RYGB. RNAs were extracted using the RNA-STAT 60 Reagent method (AMS biotechnology Europe ltd., Bioggio-Lugano, Switzerland). Reverse transcription was performed on 500 ng of total RNA using the SuperScript ${ }^{\mathrm{TM}}$ II Reverse Transcriptase (Invitrogen, Basel, Switzerland) and random primers (Promega, Catalys, Wallissellen, Switzerland). Relative expression of genes was assessed by real time PCR using the LightCycler technology (Roche Diagnostics, Rotkreuz, Switzerland) with the Quantitect Sybr ${ }^{\circledR}$ Green PCR Kit (Qiagen, Hilden, Germany). cDNAs of interest were amplified using specific primers synthesized by Microsynth (Windish, Switzerland) which are listed in table 2. All samples were quantified in at least two runs, to obtain an inter-assay coefficient variation $<10 \%$. $\beta_{2}$-microglobulin was used as the reference gene. Relative expression was then determined using crossing point values and amplification efficiencies of the target gene and the reference gene.

\section{Statistical Analysis}

All analyses were performed using the Jump 5.1 statistical package (SAS Institute, Cary, NC, USA). All data are given as mean \pm SEM, and potential differences between groups were assessed by Student's t-test. Potential univariate relationship between the levels of gene expression and BMI were done by Spearman's correlation analyses. Stepwise analysis of independent variables was used to determine possible predictors of weight loss. $\mathrm{P} \leq 0.05$ was considered statistically significant.

\section{Results}

\section{Anthropometric and Biological Measures after Surgery}

We studied a cohort of 30 women undergoing RYGB, and we recorded anthropometric and biological parameters before and after 3, 6, and 12 months following surgery. All bariatric patients significantly lost weight after surgery (fig. 1), starting with a BMI of 44.2 \pm 0.8 (range 38.1-55.9) kg/m² and reaching $29.3 \pm 1.0$ (range $22.5-36.9$ ) kg/m². At 6 months after surgery, they had lost $25.6 \pm 1.3 \%$ of their initial body weight and at 12 months $33.9 \pm 1.5 \%$. Finally at 12 months, their BMI was still increased compared to nonobese controls but not significantly different (BMI of $24.9 \pm 0.7$ (range 22.7-26.4) kg/m²). Their mean fasting insulin levels decreased from $23.6 \pm 2.5 \mathrm{UI} / \mathrm{l}$ to $16.4 \pm 1.9(\mathrm{p}=0.03), 14.0 \pm 1.4(\mathrm{p}=0.001)$ and $12.2 \pm 1.4(\mathrm{p}=0.0002)$ after 3,6 and 12 months after surgery, respectively. As their mean glucose and lipid levels were more or less in the normal range at baseline, they were not markedly modified with major weight loss (fig. 2A-F). However, at 12 months after gastric bypass, HDL-C, LDL-C, and triglycerides were still significantly lower compared to baseline (HDL-C $2.8 \pm 0.2$ vs. $3.6 \pm 0.2 \mathrm{mmol} / \mathrm{l}(\mathrm{p}=0.007) ; \mathrm{LDL}-\mathrm{C} 2.3 \pm 0.2$ vs. $2.9 \pm 0.2 \mathrm{mmol} / \mathrm{l}$ $(\mathrm{p}=0.01)$; triglycerides $1.2 \pm 0.1 \mathrm{vs} .1 .7 \pm 0.2 \mathrm{mmol} / \mathrm{l}(\mathrm{p}=0.01))$.

\section{Gene Expression at Baseline}

Figure 3 shows the mRNA expression of PPAR $\gamma 1$, PPAR $\gamma 2,11 \beta H S D 1$, and leptin in the VAT (black columns) and SAT (white columns) in both obese and nonobese women. At baseline, PPAR $\gamma 1$ was expressed at lower levels in obese patients compared to controls in both VAT and SAT $(-39 \%(\mathrm{p}=0.006)$ and $-34 \%(\mathrm{p}=0.02)$, respectively), whereas PPAR $\gamma 2$ expression was not significantly different between groups $(+10 \%(\mathrm{p}=0.68)$ and $-1 \%(\mathrm{p}=$ 0.99), respectively) (fig. 3A-B). Consistently, target genes of PPAR $\gamma$ pathway, such as the glucose transporter Glut4, were decreased in obesity (VAT $-53 \%$ ( $p=0.007$ ) and SAT $-62 \%$ $(p=0.0008))$ compared to nonobese women. In contrast, 11ßHSD1 was expressed at higher levels in obese compared to control subjects in both VAT and SAT $(2.9 \times(\mathrm{p}=0.006)$ and $2.2 \times$ $(p=0.003)$, respectively) (fig. 3C). Leptin levels were markedly enhanced in obese women 


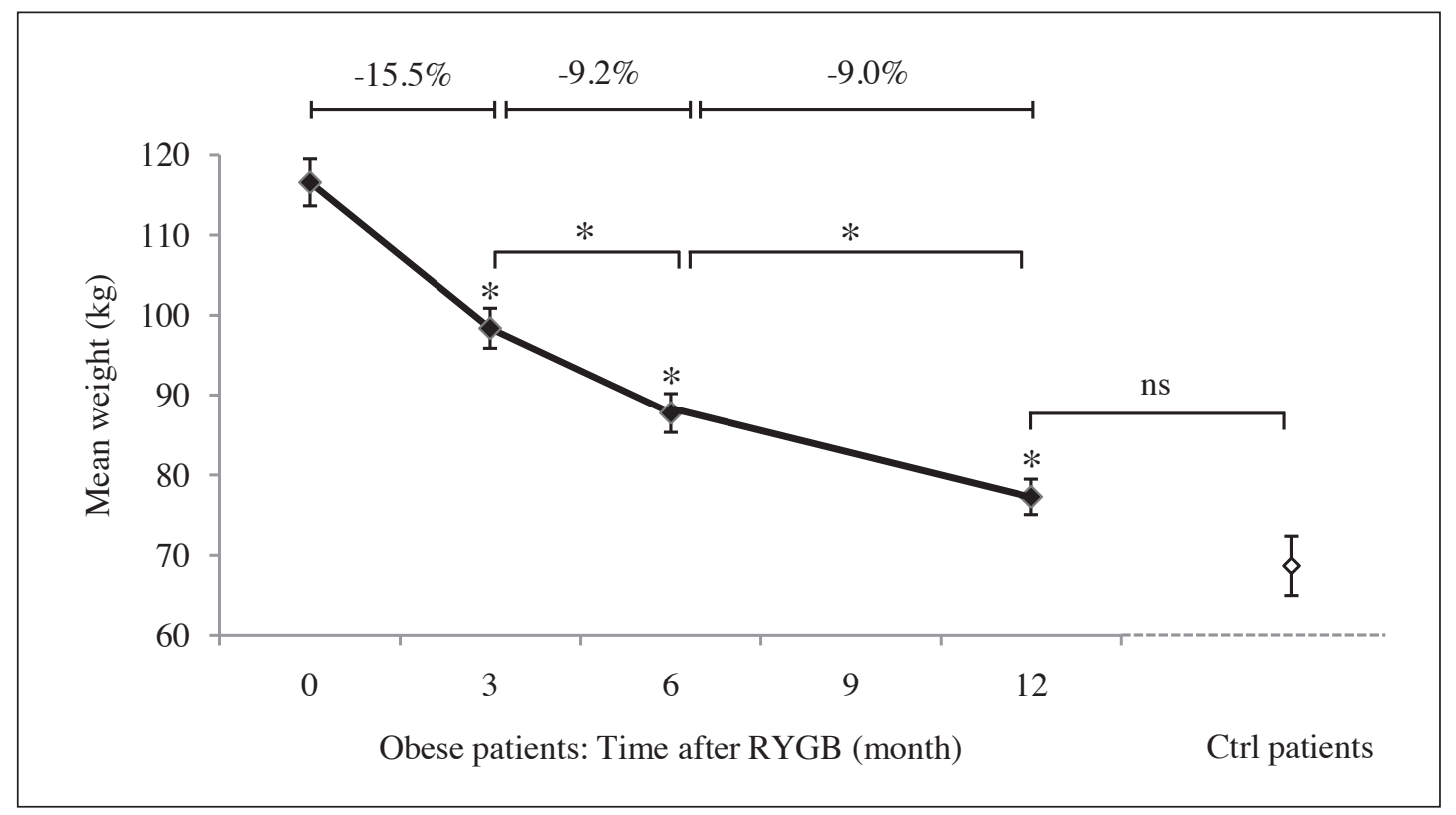

Fig. 1. Mean weight of obese patients at the time of RYGB and at 3,6 and 12 months after surgery and compared to the mean weight of control subjects (mean $\pm \mathrm{SEM}$; ${ }^{*} \mathrm{p}<0.05$ ).

Table 3. Nonparametric correlation according to Spearman between BMI and gene expression of leptin and 11ßHSD1

\begin{tabular}{llll}
\hline Variable & By-variable & Spearman RHO & Prob > RHO \\
\hline Leptin SAT & BMI & 0.4746 & 0.0165 \\
Leptin VAT & BMI & 0.5985 & 0.0016 \\
11ßHSD1 SAT & BMI & 0.4146 & 0.0393 \\
$11 \beta H S D 1$ VAT & BMI & 0.4954 & 0.0118 \\
\hline
\end{tabular}

$(7.1 \times(p=0.009)$ and $1.9 \times(p=0.03)$, respectively) (fig. 3D). In contrast, levels of adiponectin mRNA were not affected in obese women (VAT $-4 \%(\mathrm{p}=0.89)$ and SAT $-16 \%(\mathrm{p}=$ 0.51) compared to nonobese women).

\section{Gene Expression after Surgery}

We next determined the effect of weight loss on the expression of the selected genes. Leptin and $11 \beta H S D 1$ gene expression were decreased after surgery, whereas PPAR 1 expression was increased (fig. 4A, C, D). At 12 months post RYGB, these 3 genes had reached levels similar to controls. In contrast, $P P A R \gamma 2$ gene expression levels remained unchanged during weight loss following RYGB (fig. 4B). Moreover, we found a positive correlation between levels of gene expression of leptin as well as $11 \beta H S D 1$ and BMI (or weight) in both VAT and SAT (table 3). We saw no correlation between levels of $P P A R \gamma 1$ as well as PPAR 2 expression and weight or BMI.

In order to evaluate the predictive value of gene expression on weight loss, we performed a stepwise analysis. By comparing weight loss 0-6 months and 0-12 months with baseline gene expression levels, the result was significant for $11 \beta H S D 1(\mathrm{p}<0.05)$. However, we found no significant correlation between the changes of $11 \beta H S D 1$ expression levels and the decrease of weight, thus confirming the results of the stepwise analysis. 


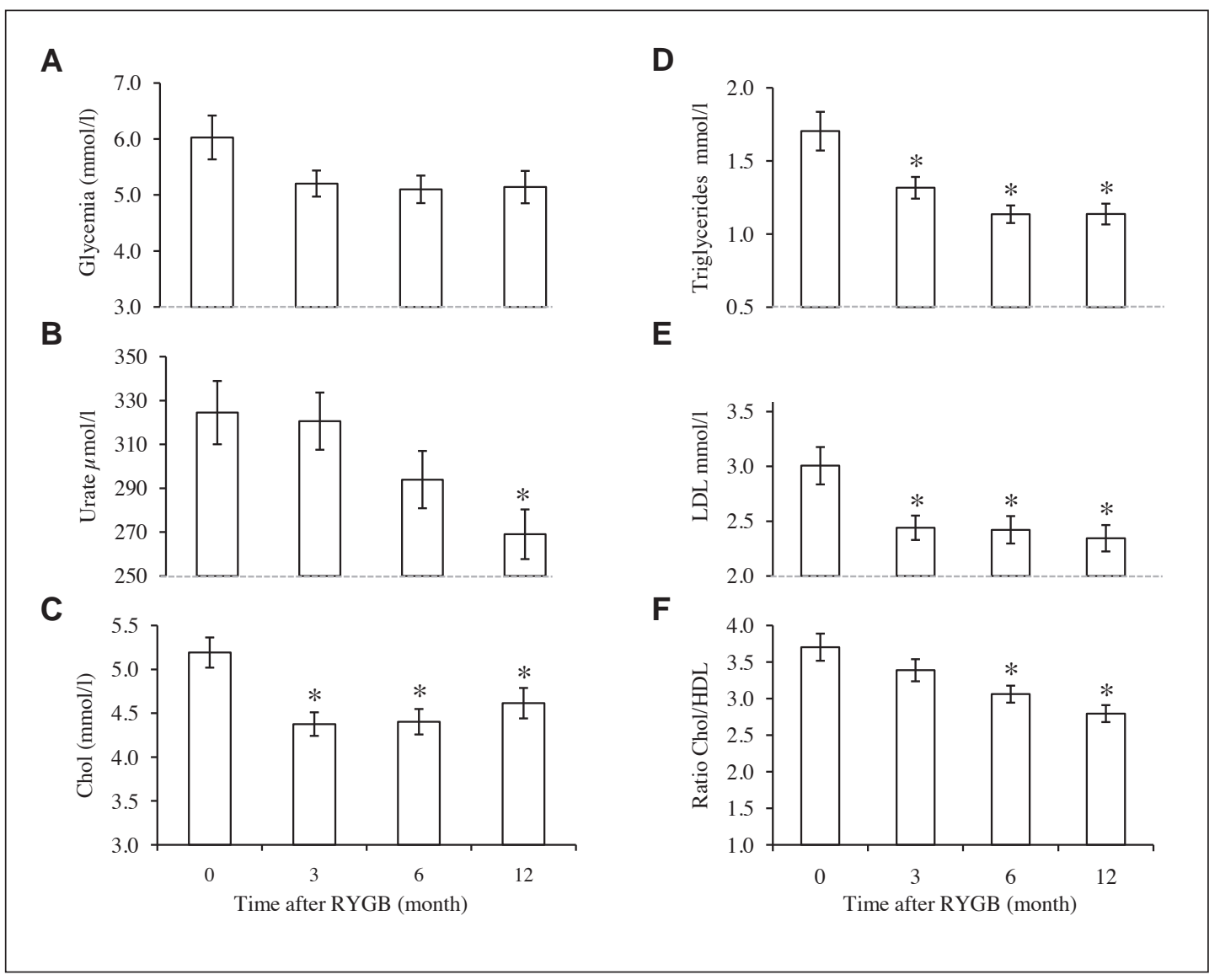

Fig. 2. Measurements of $\mathbf{A}$ glycemia, B urate, $\mathbf{C}$ cholesterol (Chol), D triglycerides, E LDL, and $\mathbf{F}$ Chol/HDL of obese patients at the time of RYGB and at 3,6 and 12 months after (mean \pm SEM; ${ }^{*} \mathrm{p}<0.05$ ).

\section{Discussion}

This study is the first detailed description of PPAR $\gamma 1, P P A R \gamma 2,11 \beta H S D 1$, and leptin gene expression in adipose tissue taking during and after RYGB surgery. The present results demonstrate that our candidate genes cannot provide conclusive predictive information and do not have immediate clinical utility. However, our data suggest that analyzing the expression of a set of genes in adipose tissue biopsied in a time-dependent manner should give preponderant information to predict weight loss.

\section{Leptin}

As expected and consistently with the literature, we found that leptin gene levels are enhanced in obesity in both VAT and SAT [33]. Although bariatric procedures are often prescribed to obese subjects, little information is available on the changes that occur in gene expression in AT during weight loss. Here, we showed that the rapid and massive weight loss following RYGB surgery resulted in the drop of leptin gene levels at 3 months of surgery, reaching levels similar to control. This result is in agreement with the work of Bastard et al. [34] who showed a 33\% decrease of leptin mRNA during a very-low-calorie diet. Although the decline of leptin gene expression was rapid, it was not due to surgery itself. Indeed, Schoff 


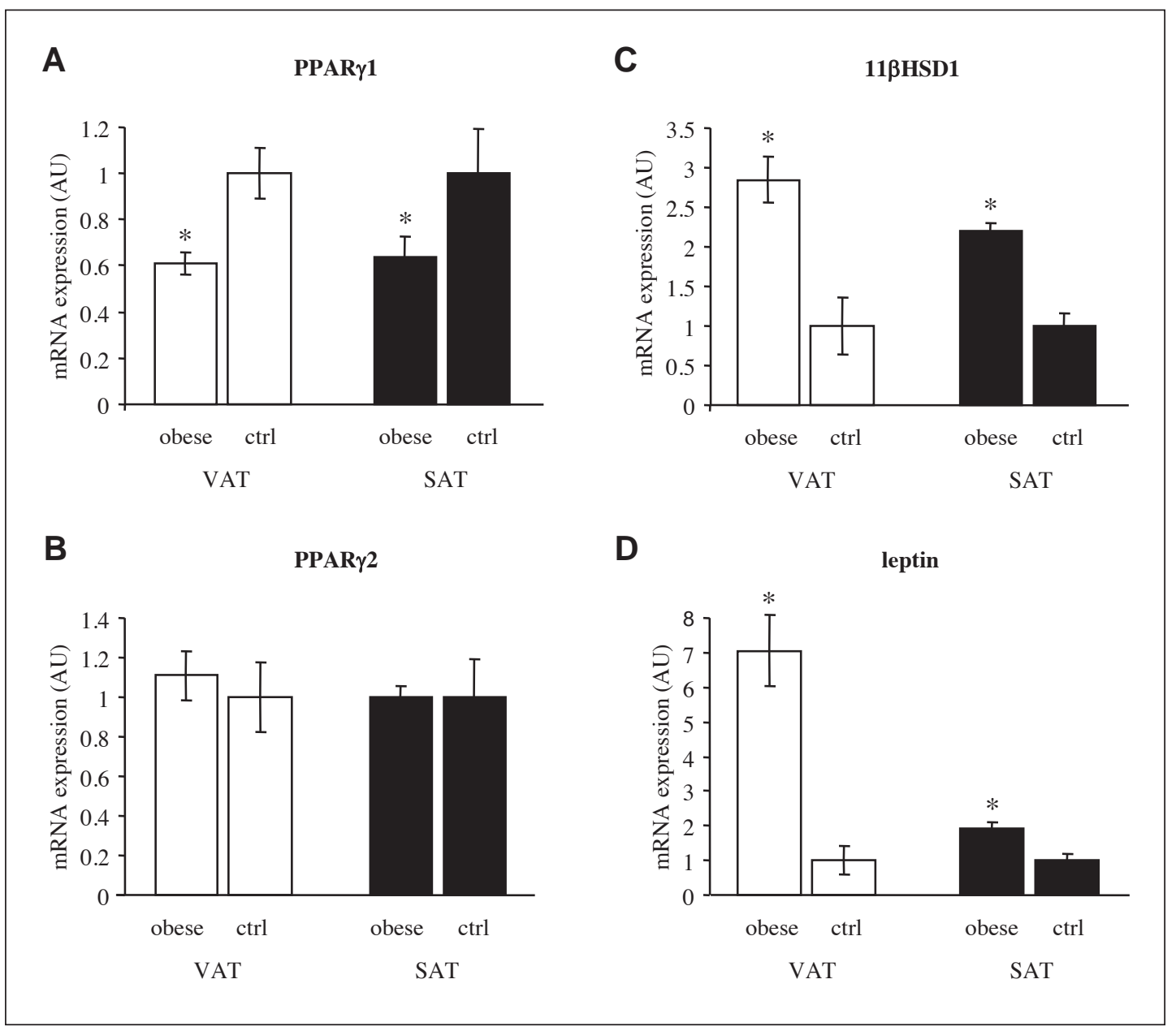

Fig. 3. Relative mRNA expression of A PPAR $\gamma 1$, B PPAR $\gamma 2$, C $11 \beta H S D 1$, and D leptin in VAT (white columns) and SAT (black columns) obtained from control (ctrl) and obese subjects. Results are expressed relatively to values of the ctrl (AU: arbitrary unit; mean \pm SEM; *p $<0.05$ ).

et al. [35] established that leptin gene expression in VAT and SAT was not changed during surgical stress. Our present observation perfectly reflected the well-known decrease of plasmatic leptin as soon as 1 month after RYGB [33, 36-39]. It is consonant with the effect of a 3-week very-low-calorie diet (weight loss of about $3 \mathrm{~kg}$ ), resulting in a decrease of leptin at the protein level in SAT [40]. In contrast, it is interesting to note that 12-week training $(-5.9 \%$ of initial body weight) leads to a decrease of plasmatic leptin concentrations, but had no effect on its gene expression in SAT [41]. Therefore, it would be interesting to look at leptin gene 2 or 3 years post RYGB, when a subset of patients regains some weight. Indeed, authors performing RYGB in rats have shown that $75 \%$ of rats that sustained weight loss had less leptin secretion compared to those unable to sustain weight loss [42,43]. Here, we observed that, in a subset of patients, leptin gene expression slightly enhanced between 6 and 12 months of surgery, although the weight of these patients was still decreasing.

The other AT-secreted proteins did not seem to have similar preponderant implication as leptin. In particular, adiponectin is one AT-secreted protein, and, although adiponectin plays an important role in glucose and lipid metabolism, it did not seem to be associated with obesity. Indeed, according to previous findings, we observed that the levels of adiponectin 
A

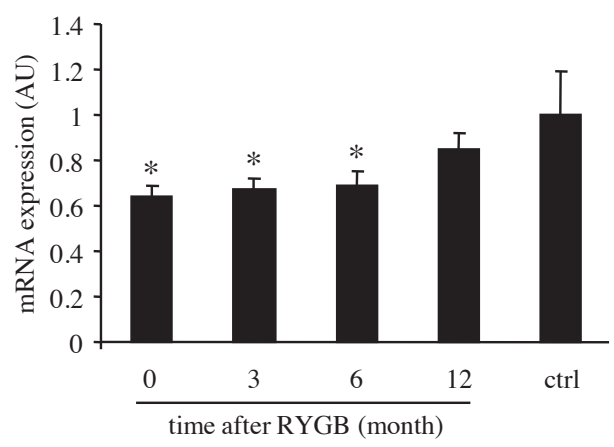

B

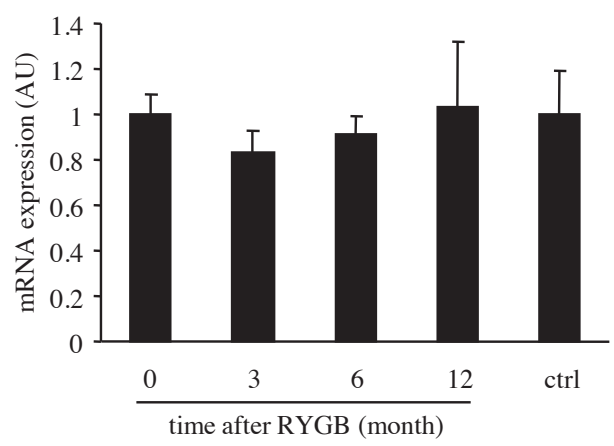

C

11ßHSD1

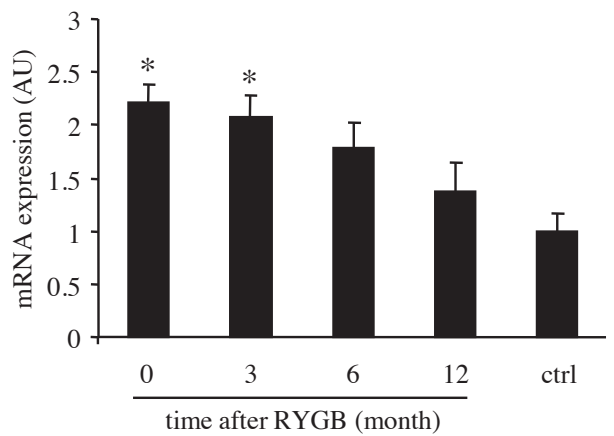

D

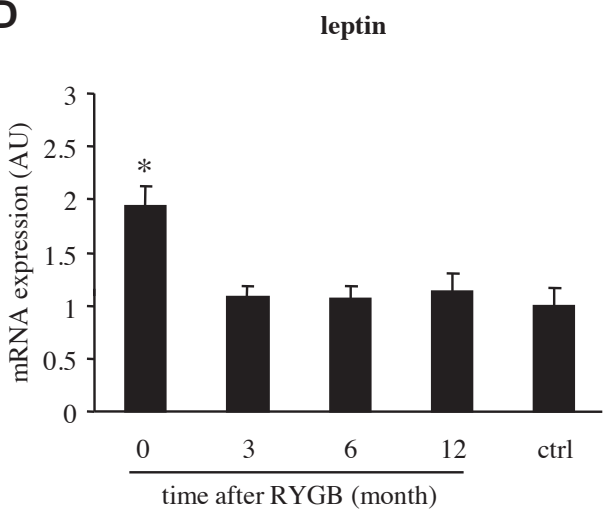

Fig. 4. Relative mRNA expression of A PPAR $\gamma 1$, B PPAR $\gamma 2$, C $11 \beta H S D 1$, and D leptin in SAT obtained from control (ctrl) and obese subjects. SAT obtained from obese women was taken during RYGB and at 3 months, 6 months, and 12 months of surgery. Results are expressed relatively to values of the ctrl (AU: arbitrary unit; mean \pm SEM; ${ }^{*} \mathrm{p}<0.05$ ).

mRNA were not affected in obese women compared to controls and by weight loss occurring after RYGB $[15,44]$. However and in contrast, adiponectin gene expression in SAT could be differently regulated in obese men undergoing RYGB [45]. Nevertheless, this should further confirmed in a larger number of male patients.

\section{PPAR $\gamma$}

PPAR $\gamma$ s are nuclear receptors that function as transcriptional regulators. Although PPAR $\gamma$ is found in a variety of human tissues, it is most highly expressed in AT [10]. More specifically, both PPAR $\gamma 1$ and PPAR $\gamma 2$ isoforms, which are derived from the same gene by alternative promoter usage and splicing, are expressed at high levels in adipocytes and macrophages [10, 46-48]. Previous studies investigating the gene expression of PPAR $\gamma$ in human AT in obesity have generated conflicting results, which were possibly due to the distinction between isoform 1 and 2 or not, to the localization of the AT, and to the mean BMI of the cohorts of patients $[10,11,13,16,49]$. Here, we showed that PPAR $\gamma 1$ and PPAR $\gamma 2$ were differently regulated in obesity. In both VAT and SAT, only PPAR $\gamma 1$ was decreased in obese women. This is consistent with a paper from Poulain-Godefroy et al. [16] who reported a 
significant decrease of PPAR $\gamma$ in SAT and a trend toward a decrease in VAT in obese normoglycemic versus lean subjects. However, although the levels of PPAR $\gamma 1$ mRNA were decreased in obesity, they were not associated with obesity, BMI, leptin gene expression in SAT and insulin [8]. Furthermore, we observed that PPAR $\gamma 1$ increased further with weight loss to reach levels similar to the controls at 12 months of surgery. For PPAR 2 , we observed a slight decrease at 3 months post surgery, but this change was not significant. These results differed from previous studies which reported a decrease of PPAR $\gamma$ following a hypocaloric diet program $[34,44,50]$. Nevertheless, they are not contradictory since Vidal-Puig et al. [10] showed that the decrease of PPAR $\gamma 2$ attributed to weight loss returns to initial levels after 4 weeks of weight maintenance. Adipose PPAR $\gamma$ appears to be an essential mediator for maintenance of whole body insulin sensitivity. It protects nonadipose tissue against lipid overload and guarantees appropriate production of adipokines such as adiponectin and leptin from adipocytes [51, 52] (reviewed in [53]). Among obese people, this balance is disturbed. PPAR $\gamma 1$ is decreased in AT, and other organs are thus not protected from excess fat. Therefore, there will be a development of metabolic comorbidities as well as leptin and insulin resistance. It is thus consistent that deletion of PPAR $\gamma$ in adipose tissues of mice protects against HFD-induced obesity and insulin resistance [54, 55].

\section{$11 \beta H S D 1$}

In AT of both origins, we found elevated levels of 11ßHSD1 in obesity consistently with previous studies [17-20,56]. Polycystic ovary syndrome and obesity are independently associated with increased expression of 11ßHSD1 [21]. Moreover, these levels were positively correlated with BMI as it was already shown in children [22]. Consistently, the levels changed to go to the normal range at 6 months of bariatric surgery.

\section{Conclusion}

Finally, is the expression of one gene sufficient to predict weight loss success? When initiating this study, we thought that one of our candidate genes could be detected as a predictive factor of the weight loss occurring after RYGB. Here, we showed that it was not the case. Indeed, neither the changes of PPAR $\gamma 1$ and 2 gene expression nor the changes of $11 \beta H S D 1$ gene expression can predict the evolution of the weight. Nevertheless, a stepwise analysis (weight loss 0-6 and 0-12 months vs. initial gene expression levels) was significant for $11 \beta H S D 1(\mathrm{p}<0.05)$. However, we found no significant correlation between the changes of $11 \beta H S D 1$ expression levels and the decrease of weight allowing confirming the pertinence of the stepwise result.

Further studies are needed to increase our understanding of the role of specific genes in weight maintenance and obesity and to define the network of genes that could be used as a biological predictor of the likelihood of success in weight loss and therefore in RYGB.

\section{Acknowledgments}

This work was supported by the Swiss National Science Foundation (grant 320000-112353 to V. Giusti) and the Center for CardioVascular and Metabolic Diseases, University Hospital Lausanne.

\section{Disclosure Statement}

There were no conflicts of interest to declare. 
Leyvraz et al.: Changes in Gene Expression Profile in Human Subcutaneous Adipose

Tissue during Significant Weight Loss

\section{References}

1 Bult MJ, van Dalen T, Muller AF: Surgical treatment of obesity. Eur J Endocrinol 2008;158:135-145.

- 2 Smith BR, Schauer P, Nguyen NT: Surgical approaches to the treatment of obesity: bariatric surgery. Endocrinol Metab Clin North Am 2008;37:943-964.

- 3 Ballantyne GH, Farkas D, Laker S, Wasielewski A: Short-term changes in insulin resistance following weight loss surgery for morbid obesity: laparoscopic adjustable gastric banding versus laparoscopic Roux-en-Y gastric bypass. Obes Surg 2006;16:1189-1197.

- 4 Gumbs AA, Modlin IM, Ballantyne GH: Changes in insulin resistance following bariatric surgery: role of caloric restriction and weight loss. Obes Surg 2005;15:462-473.

5 Cottam DR, Mattar SG, Barinas-Mitchell E, Eid G, Kuller L, Kelley DE, Schauer PR: The chronic inflammatory hypothesis for the morbidity associated with morbid obesity: implications and effects of weight loss. Obes Surg 2004; 14:589-600.

- 6 Viguerie N, Poitou C, Cancello R, Stich V, Clement K, Langin D: Transcriptomics applied to obesity and caloric restriction. Biochimie 2005;87:117-123.

7 Kim K, Perroud B, Espinal G, Kachinskas D, Austrheim-Smith I, Wolfe BM, Warden CH: Genes and networks expressed in perioperative omental adipose tissue are correlated with weight loss from Roux-en-Y gastric bypass. Int J Obes 2008;32:1395-1406.

8 Auboeuf D, Rieusset J, Fajas L, Vallier P, Frering V, Riou JP, Staels B, Auwerx J, Laville M, Vidal H: Tissue distribution and quantification of the expression of mRNAs of peroxisome proliferator-activated receptors and liver X receptor-alpha in humans: no alteration in adipose tissue of obese and NIDDM patients. Diabetes 1997;46:1319-1327.

9 Giusti V, Verdumo C, Suter M, Gaillard RC, Burckhardt P, Pralong F: Expression of peroxisome proliferatoractivated receptor-gamma(1) and peroxisome proliferator-activated receptor-gamma(2) in visceral and subcutaneous adipose tissue of obese women. Diabetes 2003;52:1673-1676.

$>10$ Vidal-Puig AJ, Considine RV, Jimenez-Linan M, Werman A, Pories WJ, Caro JF, Flier JS: Peroxisome proliferator-activated receptor gene expression in human tissues. Effects of obesity, weight loss, and regulation by insulin and glucocorticoids. J Clin Invest 1997;99:2416-3422.

-11 Krempler F, Breban D, Oberkofler H, Esterbauer H, Hell E, Paulweber B, Patsch W: Leptin, peroxisome proliferator-activated receptor-gamma, and CCAAT/enhancer binding protein-alpha mRNA expression in adipose tissue of humans and their relation to cardiovascular risk factors. Arterioscler Thromb Vasc Biol 2000;20:443-449.

12 Rieusset J, Andreelli F, Auboeuf D, Roques M, Vallier P, Riou JP, Auwerx J, Laville M, Vidal H: Insulin acutely regulates the expression of the peroxisome proliferator-activated receptor-gamma in human adipocytes. Diabetes 1999;48:699-705.

13 Bortolotto JW, Margis R, Ferreira AC, Padoin AV, Mottin CC, Guaragna RM: Adipose tissue distribution and quantification of PPARbeta/delta and PPARgamma1-3 mRNAs: discordant gene expression in subcutaneous, retroperitoneal and visceral adipose tissue of morbidly obese patients. Obes Surg 2007;17:934-940.

14 Lefebvre AM, Laville M, Vega N, Riou JP, van Gaal L, Auwerx J, Vidal H: Depot-specific differences in adipose tissue gene expression in lean and obese subjects. Diabetes 1998;47:98-103.

15 Viguerie N, Vidal H, Arner P, Holst C, Verdich C, Avizou S, Astrup A, Saris WH, Macdonald IA, Klimcakova E, Clément K, Martinez A, Hoffstedt J, Sørensen TI, Langin D: Adipose tissue gene expression in obese subjects during low-fat and high-fat hypocaloric diets. Diabetologia 2005;48:123-131.

-16 Poulain-Godefroy O, Lecoeur C, Pattou F, Fruhbeck G, Froguel P: Inflammation is associated with a decrease of lipogenic factors in omental fat in women. Am J Physiol Regul Integr Comp Physiol 2008;295:R1-7.

17 Rask E, Olsson T, Soderberg S, Andrew R, Livingstone DE, Johnson O, Walker BR: Tissue- specific dysregulation of cortisol metabolism in human obesity. J Clin Endocrinol Metab 2001;86:1418-1421.

18 Rask E, Walker BR, Soderberg S, Livingstone DE, Eliasson M, Johnson O, Andrew R, Olsson T: Tissue-specific changes in peripheral cortisol metabolism in obese women: increased adipose 11beta-hydroxysteroid dehydrogenase type 1 activity. J Clin Endocrinol Metab 2002;87:3330-3336.

19 Paulmyer-Lacroix O, Boullu S, Oliver C, Alessi MC, Grino M: Expression of the mRNA coding for 11betahydroxysteroid dehydrogenase type 1 in adipose tissue from obese patients: an in situ hybridization study. J Clin Endocrinol Metab 2002;87:2701-2705.

20 Desbriere R, Vuaroqueaux V, Achard V, Boullu-Ciocca S, Labuhn M, Dutour A, Grino N: 11beta-hydroxysteroid dehydrogenase type $1 \mathrm{mRNA}$ is increased in both visceral and subcutaneous adipose tissue of obese patients. Obesity 2006;14:794-798.

-21 Svendsen PF, Madsbad S, Nilas L, Paulsen SK, Pedersen SB: Expression of 11beta-hydroxysteroid dehydrogenase 1 and 2 in subcutaneous adipose tissue of lean and obese women with and without polycystic ovary syndrome. Int J Obes 2009;33:1249-1256.

22 Mericq V, Medina P, Bouwman C, Johnson MC, Godoy J, Lopez T, Iniquez G: Expression and activity of 11betahydroxysteroid dehydrogenase type 1 enzyme in subcutaneous and visceral adipose tissue of prepubertal children. Horm Res 2009;71:89-93.

-23 Tomlinson JW, Moore J, Cooper MS, Bujalska I, Shahmanesh M, Burt C, Strain A, Hewison M, Stewart PM: Regulation of expression of 11 beta-hyd roxysteroid dehydrogenase type 1 in adipose tissue: tissue-specific induction by cytokines. Endocrinology 2001;142:1982-1989. 
Leyvraz et al.: Changes in Gene Expression Profile in Human Subcutaneous Adipose

Tissue during Significant Weight Loss

24 Tomlinson JW, Sinha B, Bujalska I, Hewison M, Stewart PM: Expression of 11beta- hydroxysteroid dehydrogenase type 1 in adipose tissue is not increased in human obesity. J Clin Endocrinol Metab 2002;87:56305635.

25 Tomlinson JW, Moore JS, Clark PM, Holder G, Shakespeare L, Stewart PM: Weight loss increases 11betahydroxysteroid dehydrogenase type 1 expression in human adipose tissue. J Clin Endocrinol Metab 2004; 89:2711-16.

26 Yang YK, Chen M, Clements RH, Abrams GA, Aprahamian CJ, Harmon CM: Human mesenteric adipose tissue plays unique role versus subcutaneous and omental fat in obesity related diabetes. Cell Physiol Biochem 2008;22:531-538.

27 Munoz R, Carvajal C, Escalona A, Boza C, Perez G, Ibanez L, Fardella C: 11beta-hydroxysteroid dehydrogenase type 1 is overexpressed in subcutaneous adipose tissue of morbidly obese patients. Obes Surg 2009; 17:764-770.

-28 Hernandez-MoranteJJ,Gomez-Santos C, Milagro F, Campion J, MartinezJA, Zamora S, Garaulet M: Expression of cortisol metabolism-related genes shows circadian rhythmic patterns in human adipose tissue. Int J Obes 2009;33:473-480.

-29 Gomez-Abellan P, Gomez-Santos C, Madrid JA, Milagro FI, Campion J, Martinez JA, Ordovas JM, Garaulet M: Circadian expression of adiponectin and its receptors in human adipose tissue. Endocrinology 2010;151: 115-122.

-30 Gomez-Abellan P, Hernandez-Morante JJ, Lujan JA, Madrid JA, Garaulet M: Clock genes are implicated in the human metabolic syndrome. Int J Obes 2008;32:121-128.

31 Gomez-Santos C, Gomez-Abellan P, Madrid JA, Hernandez-Morante JJ, Lujan JA, Ordovas JM, Garaulet M: Circadian rhythm of clock genes in human adipose explants. Obesity 2009;17:1481-1485.

-32 Giusti V, Suter M, Verdumo C, Gaillard RC, Burckhardt P, Pralong FP: Molecular determinants of human adipose tissue: differences between visceral and subcutaneous compartments in obese women. J Clin Endocrinol Metab 2004;89:1379-1384.

33 Knerr I, Herzog D, Rauh M, Rascher W, Horbach T: Leptin and ghrelin expression in adipose tissues and serum levels in gastric banding patients. Eur J Clin Invest 2006;36:389-394.

-34 Bastard JP, Hainque B, Dusserre E, Bruckert E, Robin D, Vallier P, Perche S, Robin P, Turpin G, Jardel C, Laville M, Forest C, Vidal H: Peroxisome proliferator activated receptor-gamma, leptin and tumor necrosis factoralpha mRNA expression during very low calorie diet in subcutaneous adipose tissue in obese women. Diabetes Metab Res Rev 1999;15:92-98.

-35 Schoof E, Stuppy A, Harig F, Singer H, Carbon R, Horbach T, Kratzsch J, Rascher W, Dötsch J: No influence of surgical stress on postoperative leptin gene expression in different adipose tissues and soluble leptin receptor plasma levels. Horm Res 2003;59:184-190.

-36 Coupaye M, Bouillot JL, Coussieu C, Guy-Grand B, Basdevant A, Oppert JM: One-year changes in energy expenditure and serum leptin following adjustable gastric banding in obese women. Obes Surg 2005;15: 827-833.

37 Holdstock C, Engstrom BE, Ohrvall M, Lind L, Sundbom M, Karlsson FA: Ghrelin and adipose tissue regulatory peptides: effect of gastric bypass surgery in obese humans. J Clin Endocrinol Metab 2003;88:31773183.

-38 Infanger D, Baldinger R, Branson R, Barbier T, Steffen R, Horber FF: Effect of significant intermediate-term weight loss on serum leptin levels and body composition in severely obese subjects. Obes Surg 2003;13: 879-888.

-39 Swarbrick MM, Stanhope KL, Austrheim-Smith IT, Van Loan MD, Ali MR, Wolfe BM, Havel PJ: Longitudinal changes in pancreatic and adipocyte hormones following Roux-en-Y gastric bypass surgery. Diabetologia 2008;51:1901-1911.

40 Bastard JP, Jardel C, Bruckert E, Blondy P, Capeau J, Laville M, Vidal H, Hainque B: Elevated levels of interleukin 6 are reduced in serum and subcutaneous adipose tissue of obese women after weight loss. J Clin Endocrinol Metab 2000;85:3338-3342.

41 Polak J, Klimcakova E, Moro C, Viguerie N, Berlan M, Hejnova J, Richterova B, Kraus I, Langin D, Stich V: Effect of aerobic training on plasma levels and subcutaneous abdominal adipose tissue gene expression of adiponectin, leptin, interleukin 6, and tumor necrosis factor alpha in obese women. Metabolism 2006;55: $1375-1381$.

-42 Guijarro A, Suzuki S, Chen C, Kirchner H, Middleton FA, Nadtochiy S, Brookes PS, Niijima A, Inui A, Meguid MM: Characterization of weight loss and weight regain mechanisms after Roux-en-Y gastric bypass in rats. Am J Physiol Regul Integr Comp Physiol 2007;293:R1474-1489.

43 Meguid MM, Glade MJ, Middleton FA: Weight regain after Roux-en-Y: a significant 20\% complication related to PYY. Nutrition 2008;24:832-842.

44 Garaulet M, Viguerie N, Porubsky S, Klimcakova E, Clement K, Langin D, Stich V: Adiponectin gene expression and plasma values in obese women during very-low-calorie diet. Relationship with cardiovascular risk factors and insulin resistance. J Clin Endocrinol Metab 2004;89:756-760.

45 Savu MK, Philips SA, Oh DK, Park K, Gerlan C, Ciaraldi TP, Henry RR: Response of adiponectin and its receptors to changes in metabolic state after gastric bypass surgery: dissociation between adipose tissue expression and circulating levels. Surg Obes Relat Dis 2009;5:172-180. 
46 Ricote M, Huang J, Fajas L, Li A, Welch J, Najib J, Witztum JL, Auwerx J, Palinski W, Glass CK: Expression of the peroxisome proliferator-activated receptor gamma (PPARgamma) in human atherosclerosis and regulation in macrophages by colony stimulating factors and oxidized low density lipoprotein. Proc Natl Acad Sci U S A 1998;95:7614-7619.

47 Ricote M, Li AC, Willson TM, Kelly CJ, Glass CK: The peroxisome proliferator-activated receptor-gamma is a negative regulator of macrophage activation. Nature 1998;391:79-82.

-48 Temelkova-Kurktschiev T, Hanefeld M, Chinetti G, Zawadzki C, Haulon S, Kubaszek A, Koehler C, Leonhardt W, Staels B, Laakso M: Ala12Ala genotype of the peroxisome proliferator-activated receptor gamma2 protects against atherosclerosis. J Clin Endocrinol Metab 2004;89:4238-4242.

-49 Lefebvre AM, Laville M, Vega N, Riou JP, van Gaal L, Auwerx J, Vidal H: Depot-specific differences in adipose tissue gene expression in lean and obese subjects. Diabetes 1998;47:98-103.

-50 Vidal-Puig A, Jimenez-Linan M, Lowell BB, Hamann A, Hu E, Spiegelman B, Flier JS, Moller DE: Regulation of PPAR gamma gene expression by nutrition and obesity in rodents. J Clin Invest 1996;97:2553-2561.

-51 Kintscher U, Law RE: PPARgamma-mediated insulin sensitization: the importance of fat versus muscle. Am J Physiol Endocrinol Metab 2005;288:E287-291.

52 Moller DE, Berger JP: Role of PPARs in the regulation of obesity-related insulin sensitivity and inflammation. Int J Obes Relat Metab Disord 2003;27(suppl 3):S17-21.

-53 Sharma AM, Staels B: Review: Peroxisome proliferator-activated receptor gamma and adipose tissueunderstanding obesity-related changes in regulation of lipid and glucose metabolism. J Clin Endocrinol Metab 2007;92:386-395.

54 He W, Barak Y, Hevener A, Olson P, Liao D, Le J, Nelson M, Ong E, Olefsky JM, Evans RM: Adipose-specific peroxisome proliferator-activated receptor gamma knockout causes insulin resistance in fat and liver but not in muscle. Proc Natl Acad Sci U S A 2003;100:15712-15717.

55 Jones JR, Barrick C, Kim KA, Lindner J, Blondeau B, Fujimoto Y, Shiota M, Kesterson RA, Kahn BB, Magnuson MA: Deletion of PPARgamma in adipose tissues of mice protects against high fat diet-induced obesity and insulin resistance. Proc Natl Acad Sci U S A 2005;102:6207-6212.

56 Paulsen SK, Pedersen SB, Fisker S, Richelsen B: 11Beta-HSD type 1 expression in human adipose tissue: impact of gender, obesity, and fat localization. Obesity 2007;15:1954-1960. 